\title{
Variability, Heritability and Flowering Ability of some Sugarcane Germplasm
}

\author{
Marwa M.A. Ghallab ${ }^{1}$, Mohamed A. Ghonema and El-Araby S.R. Salem²
}

\begin{abstract}
Four experiments were conducted at El-Sabahia $\left(31^{\circ}\right.$, 12N latitude), Alexandria, Egypt Sugar Cane Research Station to estimate the variability, heritability and flowering ability of eighty eight sugar cane germplasm. All experiments were planted in mid-March 2013 and their design was randomized complete block with three replicates. Variability in important traits among tested germplasm was estimated using genotypic and phenotypic variance in addition to genotypic and phenotypic coefficients and broad sense heritability. Flowering ability was determined using the number and percentage variation of flowering germplasm and flowering dates. The results showed that the magnitude of genotypic and environmental variance was the highest in number of millable cane character and the minimum value was found in stalk diameter in plant crop and both ratoon crops. Maximum genotypic and phenotypic coefficients of variation were exhibited by cane yield and number of millable cane in plant and both ratoon crops, also in single stalk weight and sugar yield in both ration crops. Among quality characters lowest values for both coefficients were obtained by purity percent in plant and both ratoon crops. In the present experiment, moderate to high heritability estimates were observed for all characters. The results indicated that the selection is more effective in plant and both ratoon crops based on yield contributing characters having high PCV, GCV and heritability along with suitable mean value. The flowering occurred in most of studied germplasm under natural environment in El-Sabahia area but the percentage of flowered germplasm differed among studied seasons. The flowering in sugarcane germplasm commenced from November and ended up to June. Most of the germplasm flowered during December at the three seasons and followed by February at plant crop, January and February at first ratoon crop and January and March at second ratoon crop. The tested germplasm were divided into 8 groups according to their flower ability.
\end{abstract}

Keywords: sugarcane- germplasm- variabilityheritability- flowering.

\section{INTRODUCTION}

The information on the nature and the magnitude of variability present in the genetic material is of prime importance for a breeder to initiate any effective selection sugarcane breeding program. Estimation variability and heritability of important characters help the breeders selecting the best and most suitable sugarcane genotypes. The high heritability and genetic gain of economically important characters have significant role in launching an effective sugarcane breeding programme as these aspects provide views about a particular characters on which greater emphasis should be given select elite sugarcane genotype (Singh et al., 1981).

According to Anshuman et al. (2002), genetic variability and heritability are useful parameters that can help in crop improvement. Genotypic and phenotypic variance as well as genotypic and phenotypic coefficient of variation along with heritability are very much essential to improve any trait of sugarcane because this would help in knowing whether or not the desired objective can be achieved from the material (Tyagi and Singh, 1998).

Rahman et al. (2008) estimated genotypic and phenotypic variation and heritability for the characters number of millable canes, stalk height, stalk girth, 10 stalk weight, brix percentage and cane yield per hectare by studying 28 promising clones and two standard varieties of sugarcane. Anbanandan and Saravanan (2010) studied estimation of variability, high PCV, GCV and heritability were recorded for cane weight, cane yield and sugar yield. Tyagi et al. (2011) studied fourteen sugarcane genotypes and analysed different characters for variance at phenotypic and genotypic levels and broad sense heritability and they found that coefficients of variation were high for the number of millable canes, cane yield, cane weight, commercial cane sugar at 8 month stage and for sugar yield at harvesting, the highest heritability values were obtained for juice brix $\%$, juice sucrose $\%$, cane yield and sugar yield per plot.

Flowering in sugarcane is a complex physiological process which consists of multiple stages of development and each stage having specific environmental and physiological requirements (Araidi et al., 2010). Environmental factors such as diurnal temperatures. As well as intermittent occurrences of night temperature below $18^{\circ} \mathrm{C}$ during the period of floral induction, which reduces flowering intensity andlor delay seeding emergence (Coleman, 1963, Gosnell, 1973 and Adejuwon, 1988).

The process of inflorescence formation in sugarcane is difficult to define because it depends on the genotype, weather and changes that occur during the growing season (Melloni et al., 2015). There are many factors affecting flowering of sugarcane and they can be

${ }^{1}$ Breed. And genetic Dept., Sugar Crops Research Inst.ARC, Egypt.

${ }^{2}$ Plant physiology and Chemistry Dept., Sugar Crops Research Inst.ARC, Egypt.

Received July 10, 2018, Accepted August 02, 2018. 
categorized as internal (e.g. age, hormone levels (Julien, 1973 and Moore and Nuss, 1987) and external (e.g. photoperiod, temperature, moisture, nutrition (Brunkhorst, 2001; Shanmugavadivu and Roa, 2009 and Berding et al., 2010).

Among the external factors that influence flowering induction, photoperiod is of high importance (Glassop et al., 2014). Although sugarcane behaves as short-day plant, successive long nights are also required to induce flowering (Taiz and Zeiger, 2010). Even at locations where the inductive photoperiod conditions occur, the emergence of inflorescences may not be uniform, revealing that the temperature is also important for flowering (Pereira, 1985). It is believed that the minimum temperature rarely falls below $18^{\circ} \mathrm{C}$ and the maximum never exceed $32^{\circ} \mathrm{C}$ in areas with abundant flowering (Berding, 1995 and Berding et al., 2007). Moreover, temperatures below $21^{\circ} \mathrm{C}$ can delay growth and panicle emergence (Clements and Awada, 1967).

Breeding for to provide sugarcane genotype requires crosses between clones that are flowering at the same time but, in sugarcane, achieving overlapping flowering time between desired parents is not always possible Table 1.The used germplasm and their source resulting in opportunistic rather than planned crosses (Glassop et al., 2013). Ahmed and Gardezi (2017) concluded that most germplasm needs to be evaluated for flowering response with viable fuzz production to identify the best parents for future hybridization program.

The presents study aims at estimating the variability, heritability and flowering ability of eighty eight sugar cane germplasm used in Egyptian sugarcane breeding programme to increase the efficiency of these parents and to develop new sugarcane varieties.

\section{MATERIALS AND METHODS}

Four experiments were conducted at El-Sabahia (31 ${ }^{\circ}$, 12N latitude), Alexandria, Egypt Sugar Cane Research Station to estimate the variability, heritability and flowering ability of eighty eight sugar cane germplasm which presented in Table 1.

The daily mean minimum, maximum temperature and relative humidity were recorded during the induction period of years 2013, 2014 and 2015 are given in Table 2.

\section{Germplasm} Source

Co214, Co244, Co281, Co284, Co301, Co312, Co317, Co360, Co395, Co419, Co434, Co435, Co449, Co451, Co453, Co469, Co508, Co617, Co622, Co670, Co1095, Co1127 and Co1129

India

India

BO3, Bo4, BO18, BO19, BO22, Bo37-61, Bo41211 and Bo41227

54B621, 62B509 and $\mathrm{B} 36-21$

BoT49

China232

Cp27-51, Cp33-242, Cp33-243 and Cp59-56

Crystalina

EI37-10, EI37-17, EI43-48, EI1-14, EI 31-257, EI 32-38 and E162-15

$86 \mathrm{E} 409$

EH26-2

EL18-1 and EL18-4

EROS

F31-762

$\mathrm{F} 146$ and $\mathrm{F} 150$

G77/31-56, G82/4-21, G85/3-35, G85/3-39, G85/3-49, G87/15-1, G87/28-2G87/27-2, G87/29-1,

G87/31-19, G87/28-30, G87/102-14, G88/27-1, G88/5-50, G95-21, G99-122, G2003-5 and G98-87

GT54-9

IK76-22, IK76-79 and IK76-99

IR20-13 and IR23-2

Mex58-1868

N11

Ph 8013

POJ 2878

PS79-545 and PS79-546

S
Barbados

Barbados

China

USA

New Guina

Salvador

Mauritius

Hawamdia,Egypt

Salvador

Unknown

Florida, USA

Taiwan

Egypt

Taiwan

Indonesia

Iran

Mexico

South Africa

Phillippine

Java

Java

Unknown 
Table 2. Summary of meteorological data recorded El-Sabahia Sugar Cane Research station, Alexandria from 26 September to 14 October 2013, 2014 and 2015

\begin{tabular}{|c|c|c|c|c|c|c|c|c|c|c|c|c|}
\hline \multirow{4}{*}{ Days } & \multicolumn{4}{|c|}{$(2013)$} & \multicolumn{4}{|c|}{ (2014) } & \multicolumn{4}{|c|}{$(\mathbf{2 0 1 5})$} \\
\hline & \multicolumn{8}{|c|}{26 September to 14 October 26 September to 14 October } & $26 \mathrm{Se}$ & tember & to 14 & ctober \\
\hline & \multicolumn{2}{|c|}{$\begin{array}{c}\text { Temperature } \\
\left({ }^{\circ} \mathbf{C}\right)\end{array}$} & \multicolumn{2}{|c|}{$\begin{array}{c}\text { Relative } \\
\text { humidity }(\%)\end{array}$} & \multicolumn{2}{|c|}{$\begin{array}{c}\text { Temperature } \\
\left({ }^{\circ} \mathbf{C}\right)\end{array}$} & \multicolumn{2}{|c|}{$\begin{array}{c}\text { Relative } \\
\text { humidity }(\%)\end{array}$} & \multicolumn{2}{|c|}{$\begin{array}{c}\text { Temperature } \\
\left({ }^{\circ} \mathbf{C}\right)\end{array}$} & \multicolumn{2}{|c|}{$\begin{array}{c}\text { Relative } \\
\text { humidity }(\%)\end{array}$} \\
\hline & Max & Min & Max & Min & Max & Min & Max & Min & Max & Min & Max & Min \\
\hline 26 & 29 & 18 & 94 & 46 & 30 & 25 & 83 & 52 & 33 & 25 & 83 & 36 \\
\hline 27 & 28 & 19 & 94 & 46 & 33 & 23 & 94 & 37 & 30 & 21 & 83 & 40 \\
\hline 28 & 29 & 23 & 73 & 41 & 28 & 24 & 74 & 32 & 32 & 22 & 83 & 35 \\
\hline 29 & 29 & 18 & 94 & 45 & 28 & 22 & 73 & 39 & 32 & 21 & 83 & 29 \\
\hline 30 & 29 & 20 & 88 & 47 & 28 & 18 & 88 & 40 & 28 & 22 & 89 & 42 \\
\hline 1 & 31 & 17 & 100 & 46 & 28 & 18 & 88 & 36 & 28 & 22 & 83 & 40 \\
\hline 2 & 30 & 18 & 94 & 41 & 28 & 18 & 88 & 33 & 29 & 20 & 88 & 42 \\
\hline 3 & 29 & 23 & 74 & 42 & 28 & 22 & 73 & 35 & 29 & 25 & 74 & 43 \\
\hline 4 & 26 & 21 & 69 & 31 & 27 & 22 & 69 & 36 & 28 & 23 & 65 & 34 \\
\hline 5 & 24 & 19 & 64 & 41 & 27 & 20 & 83 & 47 & 28 & 23 & 65 & 33 \\
\hline 6 & 25 & 18 & 64 & 33 & 28 & 19 & 83 & 47 & 28 & 23 & 78 & 39 \\
\hline 7 & 25 & 18 & 68 & 34 & 29 & 21 & 88 & 48 & 29 & 21 & 78 & 43 \\
\hline 8 & 26 & 18 & 68 & 38 & 29 & 22 & 83 & 50 & 30 & 21 & 83 & 38 \\
\hline 9 & 27 & 21 & 69 & 48 & 29 & 19 & 94 & 51 & 29 & 24 & 69 & 42 \\
\hline 10 & 28 & 20 & 83 & 32 & 28 & 21 & 88 & 36 & 29 & 24 & 69 & 36 \\
\hline 11 & 27 & 17 & 88 & 41 & 28 & 19 & 94 & 46 & 29 & 20 & 83 & 37 \\
\hline 12 & 27 & 23 & 83 & 61 & 28 & 18 & 88 & 43 & 31 & 19 & 88 & 38 \\
\hline 13 & 28 & 23 & 83 & 63 & 29 & 18 & 94 & 43 & 29 & 20 & 94 & 57 \\
\hline 14 & 28 & 22 & 83 & 53 & 26 & 19 & 83 & 50 & 28 & 24 & 69 & 37 \\
\hline
\end{tabular}

* Source: Whether underground site.

All the experiments were planted in mid-March 2013 and their design was randomized complete block with three replicates. Each replicate consisted of eighty eight plots. Each plot contained three rows spaced $1.5 \mathrm{~m}$ apart and $4.5 \mathrm{~m}$ long. The experiments irrigation and other cultural practices were carried out as usual for inducing flowering.

The first experiment was used to study the variability, heritability and harvested in Mid-March 2014 (plant cane crop), Mid-March, 2015 (first ratoon crop), Mid-March, 2016 (second ratoon crop) and data was recorded for number of millable cane/plot, stalk length $(\mathrm{cm})$, stalk diameter $(\mathrm{cm})$, single stalk weight $(\mathrm{kg})$, number of internodes, cane yield (ton/fed.) and quality analysis was performed to estimate brix \%, pol $\%$, purity $\%$ and sugar yield (ton/fed.) for each germplasm according to Hussein et al. (2012).

Phenotypic, environmental, genetic variance and coefficient of variation for all studied characters were estimated according to Burton and DeVane (1953). The broad sense heritability was estimated according to the method suggested by Johnson et al. (1955).

The second experiment was carried out to study the flowering ability in plant cane crop (2013/2014 season).
The third was used to study the flowering ability in first ratoon crop after the harvesting in mid-march, 2014. The fourth experiment was used to study the flowering ability in second ratoon crop (2015/2016 season) after the harvesting in March 2014 and 2015. During the months from November, 2013, 2014 and 2015 to the end of June 2014, 2015 and 2016 the flowering data was recorded as follows:

1- Germplasm flowered and their percentage was counted from $1^{\text {st }}$, November to the end of June and their percentage was calculated in plant, first and second crops.

2- Flowering dates were recorded for the flowered germplasm in plant, first and second ratoon crops.

\section{RESULTS AND DISCUSSION}

\section{Variability and heritability}

The results of genetic analysis for different characters in terms of phenotypic and genotypic variance, environmental variance, genotypic coefficient of variation percent (GCV), phenotypic coefficient of variation percent $(\mathrm{PCV})$, heritability percent and general mean estimated for different characters are given in (Tables 3, 4 and 5) for plant, first and second crops, respectively. 
I-Variability in traits of studied germplasm

\section{1-Genotypic and phenotypic variance}

After partitioning of phenotypic variance, it was found that genotypic variance was higher than that of the environmental one for all studied characters in plant and both ratoon crops except in single stalk weight character $\left(\sigma^{2} \mathrm{~g}=0.0116, \sigma^{2} \mathrm{e}=0.0181\right)$ in plant crop and $\left(\sigma^{2} \mathrm{~g}=0.0194, \sigma^{2} \mathrm{e}=0.0263\right)$ in second ratoon crop (Table 3, 4 and 5). The magnitude of variance was the highest in number of millable cane $\left(\sigma^{2} \mathrm{~g}=529.67, \sigma_{\mathrm{e}}^{2}=\right.$ $168.98)$ followed by stalk length $\left(\sigma^{2} \mathrm{~g}=376.64, \sigma^{2} \mathrm{e}=\right.$ 99.03), and the minimum value was found in stalk diameter $\left(\sigma^{2} \mathrm{~g}=0.0149, \sigma^{2} \mathrm{e}=0.0056\right)$ in plant crop, also, the same trend was observed in both first and second ratoon crops. These results indicate that a negligible role was played by the environmental factors in the inheritance of these characters in sugarcane except in single stalk weight character. The high genotypic variance for number of millable cane and stalk length was reported also by (Chaudhary 2001). Singh et al. (1996) obtained lowest estimates of cane diameter.

\section{2-Genotypic and phenotypic coefficients of variation}

Cane yield (ton/fed.) and millable cane number exhibited high variability among genotypes as revealed by higher magnitude of phenotypic and genotypic coefficient variation in plant, first and second ratoon crops, also single stalk weight and sugar yield (ton/fed.) in first and second raton crops only, as shown in (Tables 3, 4 and5), suggesting that these characters are under the influence of genetic control (Verma et al., 1988; Hapse and Hapse, 1990).

Table 3. General mean, range, components of variances, coefficients of variation, heritability (broad sense) for cane yield, yield components and quality characters in plant crop

\begin{tabular}{|c|c|c|c|c|c|c|c|c|c|}
\hline \multirow{2}{*}{ Characters } & \multicolumn{2}{|c|}{ Range } & \multirow{2}{*}{$\begin{array}{c}\text { General } \\
\text { mean }\end{array}$} & \multirow{2}{*}{$\sigma^{2} e$} & \multirow{2}{*}{$\sigma^{2} \mathbf{g}$} & \multirow{2}{*}{$\sigma^{2} \mathbf{p}$} & \multicolumn{2}{|c|}{$\begin{array}{l}\text { Coefficient of } \\
\text { variation }(\%)\end{array}$} & \multirow{2}{*}{$\begin{array}{c}\text { Heritability } \\
(\%)\end{array}$} \\
\hline & Min & $\operatorname{Max}$ & & & & & Genotypic & Phenotypic & \\
\hline Millable cane number/plot & 99 & 221 & 150.67 & 168.98 & 529.67 & 698.65 & 15.27 & 17.54 & 75.81 \\
\hline Stalk length (cm) & 160 & 290 & 229 & 99.03 & 376.64 & 475.67 & 8.47 & 9.52 & 79.18 \\
\hline Stalk diameter (cm) & 1.50 & 3.20 & 2.20 & 0.0056 & 0.0149 & 0.0205 & 5.55 & 6.51 & 72.82 \\
\hline Single stalk weight (kg) & 0.65 & 2.00 & 1.25 & 0.0181 & 0.0116 & 0.0297 & 8.62 & 13.79 & 39.06 \\
\hline Number of internodes & 12.50 & 23.00 & 16.20 & 0.2211 & 0.5485 & 0.7696 & 4.57 & 5.41 & 71.27 \\
\hline Juice brix percent & 14.66 & 24.33 & 19.97 & 0.6624 & 1.7865 & 2.4489 & 6.69 & 7.84 & 72.95 \\
\hline Juice pol percent & 11.65 & 20.66 & 16.68 & 0.1220 & 0.7278 & 0.8498 & 5.11 & 5.53 & 85.64 \\
\hline Juice purity percent & 89.68 & 94.57 & 92.97 & 0.0590 & 0.4849 & 0.5439 & 0.75 & 0.79 & 89.15 \\
\hline Sugar yield (t/fed.) & 3.23 & 7.90 & 5.67 & 0.0078 & 0.3389 & 0.3467 & 10.27 & 10.38 & 97.75 \\
\hline Cane yield (t/fed.) & 35.48 & 65.74 & 48.67 & 18.01 & 168.77 & 186.78 & 26.69 & 28.08 & 90.36 \\
\hline
\end{tabular}

Whereas: $\sigma^{2} \mathrm{e}=$ environmental variance, $\sigma^{2} \mathrm{~g}=$ genetic variance, $\sigma^{2} \mathrm{p}=$ phenotypic variance.

Table 4. General mean, range, components of variances, coefficients of variation, heritability (broad sense) for cane yield, yield components and quality characters in first ratoon crop

\begin{tabular}{|c|c|c|c|c|c|c|c|c|c|}
\hline \multirow[t]{2}{*}{ Characters } & \multicolumn{2}{|c|}{ Range } & \multirow{2}{*}{$\begin{array}{l}\text { General } \\
\text { mean }\end{array}$} & \multirow[t]{2}{*}{$\sigma^{2} e$} & \multirow[t]{2}{*}{$\sigma^{2} g$} & \multirow[t]{2}{*}{$\sigma^{2} \mathbf{p}$} & \multicolumn{2}{|c|}{$\begin{array}{l}\text { Coefficient of } \\
\text { variation }(\%)\end{array}$} & \multirow{2}{*}{$\begin{array}{c}\text { Heritability } \\
(\%)\end{array}$} \\
\hline & Min & Max & & & & & Genotypic & Phenotypic & \\
\hline Millable cane number/plot & 89 & 210 & 139.80 & 115.42 & 468.34 & 583.76 & 15.48 & 17.28 & 80.23 \\
\hline Stalk length (cm) & 150 & 270 & 220 & 135.78 & 401.76 & 537.54 & 9.11 & 10.54 & 74.74 \\
\hline Stalk diameter (cm) & 1.40 & 2.90 & 2.05 & 0.0062 & 0.0154 & 0.0216 & 6.05 & 7.17 & 71.56 \\
\hline Single stalk weight (kg) & 0.55 & 1.80 & 1.16 & 0.0195 & 0.0274 & 0.0469 & 14.27 & 18.67 & 58.47 \\
\hline Number of internodes & 12.50 & 21.50 & 16.50 & 0.1131 & 1.1708 & 1.2839 & 6.56 & 6.87 & 91.19 \\
\hline Juice brix percent & 14.00 & 25.33 & 19.00 & 0.1135 & 2.8494 & 2.9629 & 8.88 & 9.06 & 96.17 \\
\hline Juice pol percent & 11.16 & 20.99 & 15.36 & 0.1994 & 0.8765 & 1.0759 & 6.09 & 6.75 & 81.47 \\
\hline Juice purity percent & 88.38 & 95.16 & 90.67 & 0.1585 & 0.5783 & 0.7368 & 0.84 & 0.95 & 78.49 \\
\hline Sugar yield (t/fed.) & 3.00 & 7.12 & 4.36 & 0.0189 & 0.3787 & 0.3976 & 14.11 & 14.46 & 95.25 \\
\hline Cane yield (t/fed.) & 28.18 & 59.87 & 45.00 & 17.21 & 187.47 & 204.68 & 30.43 & 31.79 & 91.59 \\
\hline
\end{tabular}

Whereas: $\sigma^{2} \mathrm{e}=$ environmental variance, $\sigma^{2} \mathrm{~g}=$ genetic variance, $\sigma^{2} \mathrm{p}=$ phenotypic variance. 
Table 5. General mean, range, components of variances, coefficients of variation, heritability (broad sense) for cane yield, yield components and quality characters in second ratoon crop

\begin{tabular}{|c|c|c|c|c|c|c|c|c|c|}
\hline \multirow{2}{*}{ Characters } & \multicolumn{2}{|c|}{ Range } & \multirow{2}{*}{$\begin{array}{c}\text { General } \\
\text { mean }\end{array}$} & \multirow{2}{*}{$\sigma^{2} \mathbf{e}$} & \multirow{2}{*}{$\sigma^{2} g$} & \multirow{2}{*}{$\sigma^{2} p$} & \multicolumn{2}{|c|}{$\begin{array}{l}\text { Coefficient of } \\
\text { variation }(\%)\end{array}$} & \multirow{2}{*}{$\begin{array}{c}\text { Heritability } \\
(\%)\end{array}$} \\
\hline & Min & Max & & & & & Genotypic & Phenotypic & \\
\hline Millable cane number/plot & 81 & 202 & 133.68 & 110.89 & 483.76 & 594.65 & 16.45 & 18.24 & 81.35 \\
\hline Stalk length $(\mathbf{c m})$ & 140 & 255 & 196.07 & 147.78 & 473.98 & 621.76 & 11.10 & 12.72 & 76.23 \\
\hline Stalk diameter $(\mathrm{cm})$ & 1.30 & 2.40 & 1.80 & 0.0157 & 0.0194 & 0.0351 & 7.74 & 10.41 & 55.27 \\
\hline Single stalk weight (kg) & 0.50 & 1.60 & 1.00 & 0.0263 & 0.0194 & 0.0457 & 13.92 & 21.38 & 42.45 \\
\hline Number of internodes & 11.50 & 20.50 & 16.00 & 0.2151 & 1.7397 & 1.9548 & 8.24 & 8.74 & 89.00 \\
\hline Juice brix percent & 13.20 & 25.99 & 19.33 & 0.2489 & 2.8830 & 3.1319 & 8.78 & 9.15 & 92.05 \\
\hline Juice pol percent & 11.47 & 21.97 & 15.00 & 0.2550 & 0.7363 & 0.9913 & 5.72 & 6.64 & 74.28 \\
\hline Juice purity percent & 87.38 & 95.16 & 90.50 & 0.2543 & 0.5115 & 0.7658 & 0.79 & 0.97 & 66.79 \\
\hline Sugar yield (t/fed.) & 2.77 & 5.95 & 4.07 & 0.0046 & 0.3967 & 0.4013 & 15.47 & 15.56 & 98.85 \\
\hline Cane yield (t/fed.) & 26.60 & 51.50 & 39.97 & 15.04 & 194.33 & 209.37 & 34.88 & 36.20 & 92.82 \\
\hline
\end{tabular}

Whereas: $\sigma^{2} \mathrm{e}=$ environmental variance, $\sigma^{2} \mathrm{~g}=$ genetic variance, $\sigma^{2} \mathrm{p}=$ phenotypic variance.

Bhatnagar et al. (2003) had reported high values of genotypic and phenotypic coefficient of variation for millable cane number. Tadesse et al. (2014) suggested that high GCV and PCV indicated that selection may be effective based on these characters and their phenotypic expression would be a good indication of the genotypic potential. Alam et al. (2017) reported that Individual cane weight exhibited high genotypic and phenotypic coefficient of variation.

The difference between PCV and GCV for sugar yield, cane yield and number of millable cane was narrow implying less influence of environment on the traits, as well showing high heritability in all seasons under study (Table 3, 4 and 5). Hence, simple selection could lead to better improvement, the same was also reported by earlier workers viz., Nair et al. (1980), Singh et al. (1983), Verma et al. (1988) and Ghosh and Singh (1996). Among the quality parameters juice purity per cent, juice brix per cent and juice pol per cent had low GCV and PCV values (Tables 3, 4 and 5) in all plant, first and second ratoon crops indicating the presence of limited genetic variability for these characters. These findings are in agreement with Nair et al. (1980), Singh et al. (1983) and Ghosh and Singh (1996). Stalk length, stalk diameter and number of internodes in plant, first and second ratoon crops exhibited lowest values of GCV and PCV, except stalk length was moderate in second ratoon crop only, which is in accordance with the finding of Nair et al. (1980) and Singh et al. (1996). Hiremath and Nagaraja (2016) found that high heritability with moderate GCV and PCV was exhibited by number of millable cane. It is important to note that the difference between the estimates of GCV and PCV are high for single stalk weight in plant and first ratoon crops, also in second ratoon crop it is observed for single stalk weight and stalk diameter with moderate heritability. The results revealed more effect of environment variation in expression of these traits.

\section{II-Heritability}

Genotypic coefficient of variations is not a correct measure to know the heritable variation present and should be considered together with heritability estimates. In the present experiment, moderate to high heritability estimates were found for all studied characters (Tables 3, 4 and 5) suggesting that selection of clones for these characters will be effective. Similar results were also reported by Singh et al. (1983), Kadian et al. (1997) and Patel et al. (2006). Tadesse and Dilnesaw (2014) found that traits under their study expressed high to medium heritability. Maximum heritability values for yield characters in the plant crop were obtained by Sugar yield $(97.75 \%)$, cane yield $(90.36 \%)$ and Juice purity percent $(89.15 \%)$, where Juice brix percent $(96.17 \%)$ had reported the maximum heritability in first ratoon crop followed by sugar yield $(95.25 \%)$ and Cane yield $(91.59 \%)$ suggesting that simple selection for these traits would be effective. Also, sugar yield reported the highest heritability in second ratoon crop which was $(98.85 \%)$ followed by cane yield and Juice brix percent which were (92.82 and 92.05), respectively. Tadesse et al., (2014) indicated that high heritability was recorded for characters such as sugar yield and cane yield. Moreover Dilnesaw et al., (2016) mention that heritability estimation indicated high heritability for cane yield. Tena et al., (2016) illustrated that high broad sense heritability was detected for stalk diameter, millable cane number, stalk height and pol \%, indicating that these traits could be selected easily. Alam et al. (2017) found that millable cane number, cane diameter, internodes number, stalk length and brix\% showed high heritability. Agrawal and Kumar 
(2017) reported that direct selection can be done through these characters which gave high heritability value for future improvement of varieties.

The result of present study clearly indicated the importance of cane yield, sugar yield and number of millable cane as they reveled high GCV and PCV coupled with high heritability. For developing improved sugarcane varieties Patel et al. (2006) mentioned that high heritability coupled with high GCV and PCV indicated that these traits were controlled by additive gene action. Hence, phenotypic selection could be effective in improvement of such traits.

Among the quantitative characters, number of millable cane, stalk length, stalk diameter, single stalk weight, number of internodes, juice brix per cent, juice pol per cent, sugar yield and cane yield showed wide range variation in plant and both ratoon crops in all genotypes under study (tables 3, 4 and 5) providing wide scope of selection for these traits, while relatively narrow range of variations was noticed for juice purity percent. These results are in conformity with the observation of Ghosh and Singh (1996), Patel et al. (2006), Tawfik et al. (2008) and Khaled et al. (2013).

In general, characters of millable cane number, stalk length, stalk diameter, single stalk weight, sugar yield and cane yield showed depression in first and second ratoon crops as compared to plant crop. Reduction in cane length and thickness was also reported by Sundra et al. (1989). Low values of GCV \& PCV in plant crop (Table 3) were recorded for Juice quality characters viz., Juice brix percent, juice pol. percent and juice purity percent, whereas in first and second ratoon crops GCV \& PCV had more values compared to plant cane crop indicating that these traits showed improvement in the ratoon stage reflecting more influence of genetic variance over error variance.

\section{III-Flowering ability}

Field experiments were conducted to observe flowering behavior of 88 sugarcane germplasm in plant cane, first and second ratoon crops under natural environment of El-Sabahia site (Alexandria).

\section{1-Germplasm flowered percentage}

The results (Table 6) showed that flowered of sugarcane germplasm planted was 55.7, 79.5 and 59.1 in 2013/2014 flowering season in plant cane crop, 2014-2015 flowering season (first ratoon crop) and
2015/2016 flowering season (second ratoon crop), respectively.

The optimum photoperiod in decreasing day length of $12: 00$ to $11: 30$ hours and the minimum and maximum temperature close to inductively ranges (Table 2) occurs from 26 September to 14 October at El-Sabahia (cane flowering site is coastal area situated at, Alexandria, Egypt). These agree with Rao et al. (1973). These numbers of inductive cycles consider the minimum to induce some sugarcane genotypes to flower (Coleman 1963 and Malik 2011). The variation of flowering genotypes percentage among years due to the difference in temperature and relative humidity among the studied years at the induction period and also the variation between genotypes effected.

Both maximum and minimum temperature were within acceptable limits for induction to take place in all studied years in El-Sabahia. In 2013 maximum temperature $\geq 31^{\circ} \mathrm{C}$ was one day only while minimum temperatures $\leq 18^{\circ} \mathrm{C}$ was eight days and the maximum relative humidity was less than $80 \%$ on eight days of induction priod seven days of them from 3-9 October. In 2014, maximum temperature $\geq 31^{\circ} \mathrm{C}$ was one day only while minimum temperatures $\leq 18^{\circ} \mathrm{C}$ was five days and the maximum relative humidity was higher than $80 \%$ all the days of induction proid ecxpte four days was lower. There were four days $\geq 31^{\circ} \mathrm{C}$ and minimum temperature within the range in 2015 and the maximum relative humidity was less than $80 \%$ at eight days of the induction proid five of them from 3-7 October. However these agree with Gosnell (1973) who expected a good inverse correlation between the amount of flowering and the number of nights when the minimum temperature drops below $18^{\circ} \mathrm{C}$, where this number is 10 or more, flowering woud be expected to be severely inhibited.

The results showed a small amount of flowering percentage in 2013 year may be related to the more number of minimum tempreture days at that year.

Pereira et al. (1983) reported that possible to forecast flowering based on occurrence of maximum and minimum daily temperatures during the inductive photoperiod. The frequency of nights with $\mathrm{T} \min \leq 18^{\circ} \mathrm{C}$ and $\mathrm{T} \max \geq 31{ }^{\circ} \mathrm{C}$ discriminted these years.

Temperatures below 18.2 are considered non inductive. Sugar cane required at least 10 inductive nights for flowering But 15 nights are ideal.

Table 6. The percentage of full flowering germplasm during plant crop, $1^{\text {st }}$ and $2^{\text {nd }}$ ratoons at El-Sabahia, Alexandria, Egypt

\begin{tabular}{ccc}
\hline Seasons & No of flowering genotypes & \%of flowering genotypes \\
\hline Plant crop (2013-14) & 49 & 55.7 \\
First Ratoon (2014-15) & 70 & 79.5 \\
Second Ratoon (2015-16) & 52 & 59.1 \\
\hline
\end{tabular}


Non inductive nights delay panicle development (Berding, 1981).

High relative humidity is critical for the induction and development of panicle (Moore and Nuss, 1987). In Egypt Amin et al. (1971) indicated that it was necessary to raise the humidity level while induction treatment took place in order to obtain flowers. In general, moisture deficit during the inductive period delays (Chu and Serapion, 1971) and reduces (Humbert et al., 1969) flowering.

If the specific day length, temperature and moisture requirement are not satisfied, flowering is inhibited or the intensity is reduced (Loch et al., 1999) and moisture stress (Pereira et al., 1983) that affected the timing and intensity of flowering.

Despite the influence of climate conditions on flowering, the intensity of this process will be also controlled by the genotype, since some genotypes can flower and other not at the same climate in this study, similar results was obtained by Shanmugavadivu and Rao, (2009) who reported that at the same climate conditions some cultivars present flowers whereas other not. The number of induction cycles varies depending on variety to be induced as reported by Julien (1971) the same finding was reported by Paliatseas and Chilton (1956). A successful number of inductive photoperiods (12-35 days) in sugarcane were depending upon the genotypes (James and Miller, 1971 and Julien, 1973).

\section{2-Flowering dates}

The flowering in sugarcane genotypes at El-Sabahia commenced from November and ended up to June, Figure (1) shows significant differences in flowering date at the three seasons. Most of the varieties flowered during the month of December at the three seasons and followed by February at plant crop, January and February at first ratoon crop and January and March at second ratoon crop. Only few genotypes could flower at May and June at the three seasons (Figure 1). The difference of the time of flowering due to the variation among genotypes in panicle development. This agree with Miah and Paul (2008) who shows a range of variation among the varieties in sugarcane flowering. Among germplasm material at NSCRI Thatta some varieties exhibit early flowering, some are midflowering and some are late (Junejo et al., 2012).

Wide range of flowering dates from 1.14 to $38.64 \%, 1.14$ to 31.82 and 1.14 to 22.73 was observed in the plant crop, first and second ratoon crops, respectively (Figure1).

Among the genotypes studied, some of the genotypes were found as regular flowers that flowered during the three seasons of study, non-flowers genotypes at any seasons, while other genotypes were flowers at one or two season only as shown in Table (7). This results agree with those found by Sartoris (1939).

The results in Table (7) illustrated that the studied germplasm could be classified into eight group acording to their flowering ability.

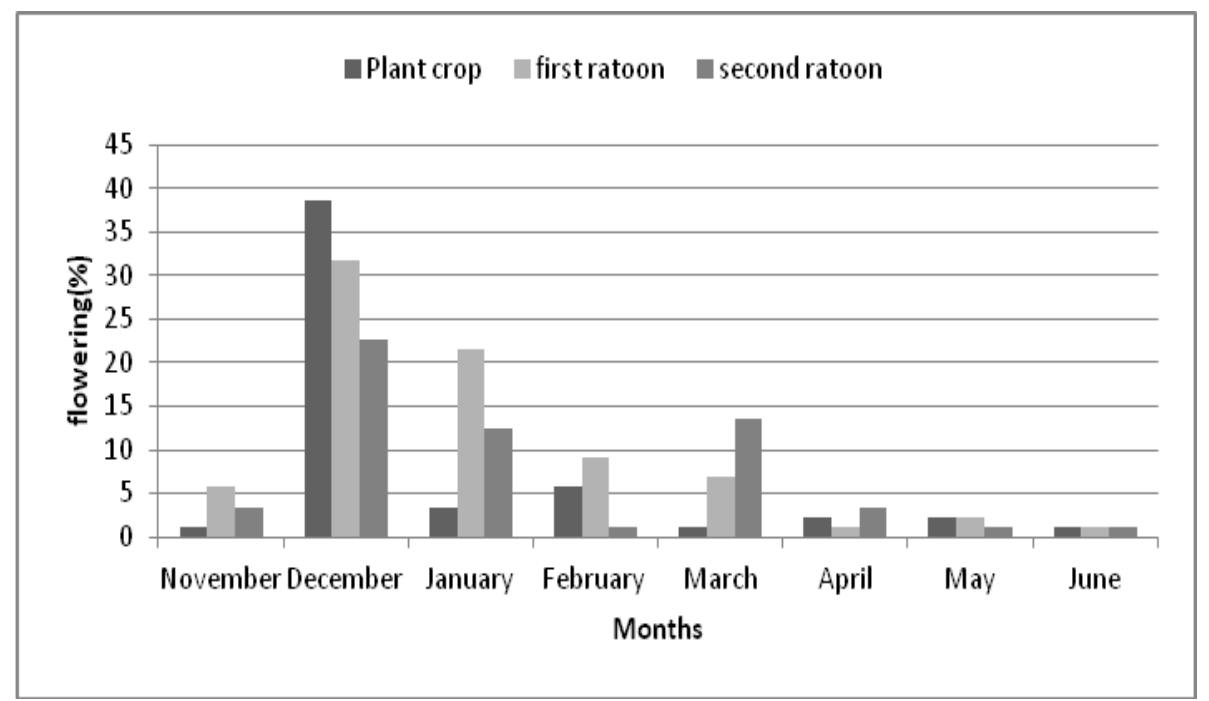

Figure 1. Mean percentage of flowering varieties from November to June at plant crop ratoon1 and 2 at El-Sabahia, Alexandria, Egypt. (LSD=1.5014). 
Table 7. Flowering behavior of studied germplasm at plant, first and second ratoon crops

\begin{tabular}{ll}
\hline Groups & Name of genotypes \\
\hline $\mathbf{1}$ & 54B621, B3621, BO3, BO41211, BO41227, BO3761, BO49, China232, Co214, Co244, Co312, \\
& EI32-38, CP27-51, Co1127, Co670, Co360, Co508, Co469, Co435, Co449, Co395, EI37-10, \\
& EI43-48, G95-21, G99-122, Ph80-13, E18-1, G87/29-1, BO3, Co1129, IK76-22, Co617, IK76- \\
& 79, EI31-257 and F31-762 \\
$\mathbf{2}$ & BO22, Co284, Co451, Co419, G77/31-56, EI1-14, G87/102-14, Mex58-1868 and 86E409 \\
$\mathbf{3}$ & Co317, Co434,EI37-17,G2003-5 \\
$\mathbf{4}$ & Co281, CP59-56, CP33-242, Co1095, GT54-9, S, G85/3-35, G85/3-49, G87 \\
& /27-2, G87/28-30, EH26-2 and Co622 \\
$\mathbf{5}$ & N11 \\
$\mathbf{6}$ & Crystalina,G98-87, PS79-546, G82/4-21, G87/28-2, 62B509, G87/15-1, IR23-2, IK76-99, \\
$\mathbf{7}$ & G88/27-1, G87/31-19, EROS, POJ2878 and G85/3-39 \\
$\mathbf{8}$ & PS79-545 \\
& BO18, BO19, Co301, E162-15, Co453, IR28-10, CP33-243, IR20-13, F150, El18-4, F146 and \\
\hline
\end{tabular}

Group 1: The genotypes flowered in plant crop, first and second ratoon. Group 2: The genotypes flowered in plant crop and first ratoon

Group 3: The genotypes flowered in plant crop and second ratoon. Group 4: The genotypes flowered in first and second ratoon.

Group 5: The genotypes flowered in plant crop only. Group 6: The genotypes flowered in first ratoon only.

Group 7: The genotypes flowered in second ratoon only. Group 8: The genotypes did not flower at any seasons.

\section{Group1}

Contains 35 germplasm that flowered in all the three seasons under study.

\section{Group 2}

Contains 9 genotypes which flowered at plant crop and first ratoon crop but non-flowering at second ratoon crop.

\section{Group3}

Contains four germplasm which flowered at plant crop and second ratoon crop while non-flowering at first ratoon crop.

\section{Group 4}

Contains 12 germplsms which flowered at first and second ratoon crops but non-flowered at plant crop.

\section{Group5}

Contains only one germplasm (N11) flowered at plant crop and non-flowering at first and second ratoon crops.

\section{Group6}

Contains 14 genotypes flowered at first ratoon crop and non-flowering at plant crop or second ratoon crop.

\section{Group7}

There was only one germplsm (PS79-545) flowered at second ratoon crop and non-flowering at plant crop or first ratoon crop.

\section{Group8}

This is the last group contains a 12 genotypes did not flower at the three seasons. These non flowering germplasm could be attributed to the number of the inductive cycle prevailing under El-Sabahia site not optiumum for induction of these germplasm.

\section{REFERENCES}

Adejuwon S.A. 1988. An Assessment of the Patterns of Rainfall Functions Between 1922 and 1985 in Nigeria. (Ph.D Thesis presented to the department of geography. Obafemi Awolowo Univ., Ile-Ife).

Agrawal R.K. and B. Kumar.2017. Variability, heritability and genetic advance for cane yield and its contributing traits in sugarcane clones under waterlogged condition. Int. J. Curr. Micr. App. Sci. 6(6): 1669-1679.

Ahmed M.S. and D.A. Gardezi.2017. Multivariate analysis in determining morphologically diverse sugarcane genotypes (Saccharumofficinarum L.) and their response to flowering at Arja, Azad Kashmir. Sarhad J. Agric. 33(1): 90-102.

Alam M.N., U.K. Nath, K.M.R. Karim, M.M. Ahmed and R.Y. Mitul.2017. Genetic variability of exotic sugarcane genotypes. Scientifica. 5202913: 1-9.

Amin M.H., E.S. Kassim, M. Bayaumi and A.Z. Menshawi.1971. Growth and flowering of sugarcane in relation to photoperiod and air humidity. Proc ISSCT. 14: 352-384.

Anbanandan,V. and K. Saravanan.2010. Genetic variability in interspecific and intergeneric progenies in sugarcane. Plant Archives. 10(2): 627-632.

Anshuman S., P.K. Bhatnagar, A.Q. Khan and P.K. Shrotria.2002. Variability and heritability for cane yield, its components and quality characters in sugarcane (Saccharumspp complex). Ind. Sugar J. 53(4): 717-719.

Araidi R., F.M.L. Silva, E.O. Ono and I.D. Rodriquez.2010. Flowering in sugarcane. Clience Rural. 40(3): 694-702. 
Berding N. 1981. Improved flowering and pollen fertility in sugarcane under increased night temperature. Crop Science. 21: 863-867.

Berding N. 1995. Improving Flowering through Breeding: Progress and Prospects. Inter. Soc. of Sugar Cane Tech. 17: 162-171.

Berding N., R.S. Pendrigh and V. Dunne.2007. Can flowering in sugarcane behavior by use of differential declinations for the initiation and development phases? Proc. Int. Soc. Sugar Cane Tech. 26: 699-711.

Berding N., R.S. Pendrigh and V. Dunne.2010. Pursuing higher efficacy for managed photoperiodic initiation of sugarcane flowering in the tropics. Sugarcane Int. 32(5): 234-250.

Bhatnagar P.K., A.Q. Khan, A. Singh and K.A. Khan.2003.Studies on genetic variability, heritability and genetic advance in plant and ratoon crops of sugarcane. Ind. Sugar.53(3): 183-185.

Brunkhorst M.J. 2001.A preliminary investigation into the effect of plant nutrient levels on sugarcane flowering. Proc. South African Sugar Tech. Assoc. 75: 143-150.

Burton, G.W. and E.H. DeVane.1953. Estimations of heritability in tall festca (Festuca arundinacea) from replicated clonal materials. Agron. J. 45: 478-481.

Chaudhary R. R. 2001. Genetic variability and heritability in sugarcane. Nepal Agric. Res. J. 4(5): 56-59.

Chu T.L. and J.L. Serapion .1971. Flower initiation and tassel emergence in sugarcane. J. Agri. Univ. Puerto Rico. 55: 101-115.

Clements H.F. and M. Awada .1967. Experiments on the artificial induction of flowering in sugarcane. Proc. Int. Soc. Sugar Cane Technol. 12: 795-812.

Coleman R.E. (1963). Effect of temperature on flowering of sugarcane. Int. Sugar J., 65: 351-354.

Dilnesaw Z., F. Tadesse, M. Biqila, F. Goshu and B. Tolera .2016. Participatory variety selection genetic variability and heritability of ten exotic commercial sugarcane varieties at Finchaa sugar factory Huru Gudro zone Oromiya Regional State Ethiopia. E. C. Agric.3(4): 719727.

Ghosh J. and J.R.P. Singh.1996. Variability in early maturing clones of sugarcane (Saccharumspp). Co-operative Sugar. 27(5): 341-344.

Glassop D., A.L. Rae and G.D. Bonnett.2013. Sugarcane flowering genes and pathways in relation to vegetative regression. Proc. Inter. Soc. Sugar Cane Tech. 28: pp: 9.

Glassop D., A.R. Graham and D. Bonnett .2014. Sugarcane flowering genes and pathways in relation to vegetative regression. Sugar Tech. 16(3): 235-240.

Gosnell J.M. 1973. Some factors affecting flowering in sugarcane. Proc South Afr. Sugar Cane Tech. Assoc. 47: 144-147.

Hapse R.S. and D.G. Hapse.1990. Genetic variability studies in late maturing sugarcane varieties. Bharathiya Sug. 15: 13-16.
Hiremath G. and T.E. Nagaraja .2016. Genetic variability and heritability analysis in selected clones of sugarcane. Inter. J. Sci. Tech. Eng. 2(8): 341-343.

Humbert R.P., G.M. Lima and J. Goveas.1969. Tassel control progress with Reglone in the Mexican sugar industry. Proc. Int. Soc. Sugar Cane Technol. 13: 462-467.

Hussein M. Al-Sayed, H. S. Fateh, W.M. Fares and Ahmed S. Attaya .2012. Multivariate Analysis of Sugar Yield Factors in Sugar Cane.American-Eurasian Journal of Sustainable Agriculture.6(1): 44-50.

James N.I. and J.D. Miller.1971. Shoot apex development in early-mid and late-season flowering sugarcane clones. Proc. Int. Soc. Sugar Cane Tech. 14: 334-340.

Johnson G.H., H.F. Robinson and R.E. Comstock. 1955. Estimation of genetic and environmental variability. Soya bean Agro. J. 47: 314-318.

Julien M.H.R. 1971. The photoperiodic control of flowering in Saccharum. Proc. Int. Soc Sugar Cane Tech. 14: 323-333.

Julien M.H.R. 1973. Physiology of flowering in Saccharum. J. Exp. Bot. 24: 549-557.

Junejo R.N. Panhwar, B.R. Kazi, A.A. Junjo, U.A. Talpur, G.M. Kaloi and M. Zubair.2012. Study of sugarcane germplasm varieties for flowering abiliaty under agroclimatic conditions of Thatta. J. Animal and plant Sci. 22(3): 688-694.

Kadian, S.P., S.V. Singh, P.S. Subharwal and J.S. Yadav.1997. Variability, heritability and genetic advance for yield And yield contributing characters in sugarcane (Saccharum Hybrid Spp.). Agric. Sci. Digest. 17(1): 5153.

Khaled K.A.M., M.S. Saleh and E.A.M. Amer.2013. Estimation of Genetic Variance and Broad Sense Heritability for Sugarcane. Alex. Sci. Exch. J.34: 121 127.

Loch D.S., B.G. Cook and G.L. Harvey.1999. Crop establishment. In: Loch, D.S. and Ferguson, J.E. (eds) Forage Seed Production Volume 2: Tropical and Subtropical Species. pp. 141-157. (CAB International: Oxon, UK).

Malik K.B. 2011. Cane and sugar production. Published by Punjab Agricultural Research Board. Tecnologies for the prosperity of agricultural stakeholders, Pp.: 52.

Melloni M.L.G., M.N.G. Melloni, M.S. Scarpari, J.C. Garcia, M.G.A. Landell and L.R. Pinto .2015. Flowering of sugarcane genotypes under different artificial photoperiod conditions. American J. Plant Sci. 6: 456-463.

Miah M.A. and N.K. Paul.2008. Effect of photoperiodic treatments on teaseling in sugarcane. Pakistan Sugar J. 23(30): 12-17.

Moore P.H. and K.J. Nuss.1987.Flowering and flower synchronization. In: Sugarcane Improvement Through Breeding by Heinz D.J. ed. Elsevier, Amsterdam, New York, Tokyo, pp. 273-311. 
Nair N.V., K.G. Somarajan and N. Balasundaram.1980. Genetic variability, heritability and genetic advance in Saccharumofficinarum. Int. Sugarcane J.XXX II:275-276.

Paliatseas E.D. and S.J.P. Chilton.1956. The induction of the emergence of the inflorescence of sugarcane. Proc. Int. Soc. Sugar Cane Tech. 9: 657-664.

Patel K.C., A.I. Patel, S.C. Mali, D.U. Patel and R.D. Vashi.2006.Variability, correlation and path coefficient analysis in sugarcane (Saccharum Spp). Crop Res. 32(2): 213-218.

Pereira A.R. 1985. Previs?o do florescimento em cana-deaç?car. Comunicaç?o da Pesquisa Agropecu?ria, 3: 15-16.

Pereira A.R., V. Barbieri and N.A.V. Nova.1983. Climatic conditioning of flowering induction in sugarcane. Agricultural Meteorology.29: 103-110.

Rahman, M.M., B.P. Podder, M.A. Rahim and K.M.R. Karim.2008. Estimates of genotypic and phenotypic variation, heritability and genetic advance under some characters of sugarcane clones. Indian Sugar. 58(4): 3136.

Rao R.R., A.H. Nour and M.A. El-Manhaly .1973. Flowering of sugarcane in Egypt. I. S. J., 75: 241-244.

Sartoris G.B. 1939. The behavior of sugarcane in Relation to length of day. Int. Soc. Sugar cane Technol. Proc. $6^{\text {th }}$ conger. 6: 796-801

Shanmugavadivu R. and P.G. Rao.2009. A comparison of flowering behavior of sugarcane clones in two different locations. Sugar Tech. 11(4): 401-404.

Singh A.P., A. Chattarjee and G.K. Nema .1996. Genetic variability. In: Sugarcane (Saccharum Spp. Complex). Crop Res. 12(2): 162-164.

Singh H.N., S.B. Singh, R.V.S. Chauhan and R.S. Vishwakarma.1983. Variability for yield and quality in sugarcane. Ind. J. Agric. Sci. 53: 786-789.

Singh R.R., B.K. Tripathi and S. Lal.1981. Variability and correlation studies in sugarcane. Indian Sugar. 31(7): 457459.
Sundra B.M., B. Sankaranaryana and G.R. Batcha .1989. Varietal Characteristics affecting ratooning potential of sugarcane. Sugar Issu. 6(1): 37-40.

Tadesse F. and Z. Dilnesaw 2014. Genetic variability, heritability and character association of twelve sugar cane varieties in Finchaa sugar estate west Wolega zone Oromia region of Ethiopia Int. J. Adv. Res. Biol. Sci. 1(7): 131-137.

Tadesse F., T. Negi, A. Getaneh, Z. Dilnesaw, N. Ayele and Y. Teferi.2014. Genetic variability and heritability of ten exotic sugar cane genotypes at Wonji sugar estate of Ethiopia. Glob Adv. Res, J. of Phys. App. Sci. 3(4): 1-4.

Taiz L. and E. Zeiger.2010. Flowering of Sugarcane Genotypes under Different Artificial Photoperiod Conditions. Plant Physiology. 6th Edition, Sinauer Associates, Sunderland.

Tawfik Y.H., A.H.S. Al-Labbody and S.R.E. El-Sheik.2008. Estimation of Genetic Variance and Broad Sense Heritability of Sugar Cane (Saccharum Spp. L.). Alex. Sci. exch. J. 29: 77-84.

Tena E., F. Mekbib and A. Ayana .2016. Heritability and correlation among sugar cane (Saccharum spp.) yield and some agronomic and sugar quality traits in Ethiopia. Am. J. Plant Sci. 7: 1453-1477.

Tyagi S.D. and D.N. Singh.1998. Studies on genetic variability for stalk characters in sugarcane. Ind. Sugar. XL VIII259-262.

Tyagi V. K., S. Sharma, and j,S.B. Bhardwa.2011. A study on the nature and magnitude of variations in different traits in sugarcane. Electronic Journal of Plant Breeding, 3: 334341.

Verma P.S., R.P.S. Dhaka and H.N. Singh.1988. Genetic variability and correlation studies in sugarcane. Ind. J. Genet. 48: 213- 217. 


\title{
الملخص العربي
}

\section{التباين الوراثى والقدرة على التوربث والازهار في بعض الاصول الوراثية لقصب السكر}

\author{
مروي مهدي غلاب و محمد عبد المنعم غنيمة و العربي سالم رمضنان
}

وكذلك اقل قيم كانت فى النسبة المئوية للنقاوه من بين صفات الجوده وذللك فى كل من محصول الغرس والخلف. وجد كذلك ان القدره على التوريث نزاوحت بين المتوسطة و العالية وذلك للصفاث تحت الدراسة. ايضـا أوضحت النتائج أن الانتخاب فى القصب الغرس ومحصول الخلف معاً اكثر فعالية وذلك للصفات المرثبطة بالمحصول والتى لها معدل توريث عالى وكذللك معامل الاختلاف الوراثي و المظهري لها مرتفع بجانب متوسط مناسب لقيم هذه الصفات.

واوضحت النتائج حدوث تزهير في معظم الاصول الوراثية المستخدمة فى الدراسة تحت الظروف الطبيعية لمحطة بحوث الصبحية ولكن نسبة التزهير في الاصول الوراثية اختلفت بإختلاف المواسم والتي فيها امتد موسم التز هير من نوفمبر الى يونيو • ووجد ان معظم الاصول الوراثية ازهرت خلال شهر ديسمبر في المواسم الثثلثة يلى ذلك شهر فبر اير في القصب الغرس ويناير وفبر اير في محصول الخلفة الاولى ويناير ومارس في محصول الخلفة الثانية وتم تقسيم الاصول الور اثية المختبرة الى ثمانية مجمو عات طبقاً لمقدرتها على
أجريت أربع تجارب بمحطة بحوث قصب السكر بالصبحية- مدينة الاسكندرية (اس م ، NI خط العرض) وذلك لتقدير التباين الوراثى و البيئى والقدره على التوريث وكذلك القدرة على إزهار ثمانية وثمانين أصل وراثي من قصب السكر. وقد تم زر اعة جميع التجارب في منتصف مارس برا.r وتم إستخدام تصميم القطاعات كاملة العشو ائية فى ثلاث مكرر ات.

وتم تقدير الاختلافات في الصفات المهمة بين الاصول الوراثية المختبره باستخدام التباين الوراثي والتباين المظهري بالاضافة الى معامل الاختلاف الوراثي و المظهري كما تم تقدير القدره على التوريث بمعناها الواسـع وتم تقدير القدره على التزهير باستخدام عدد ونسبة الاصول الور اثية التي ازهرت وميعاد نز هيرها. و أوضحث النتائج ان صفة عدد العيدان القابلة للعصر كانت الاعلى فى قيم التباين الوراثى والبيئى بينما سمك العود هى الاقل في تلك القيم وذلك فى كل من القصب الغرس والخلف. وجد ايضا ان اعلى قيم لمعامل الاختلاف الوراثى والمظهرى كانت فى صفات عدد العيدان القابلة للعصر ووزن العود ومحصول السكر ومحصول العيدان 